Trouessart, E.-L. La pluralité des espèces de gorille. Bull. Mus. d'Hist. nat., pp. 102-108, 191-196 (1-13 of reprint), 9 figs. 1920. (Material in the Paris museum shows that two distinct species of gorilla inhabit West Africa; the Gorilla beringei mikenensis of Lönnberg, from the lake region, is regarded as representing a third very distinct species.)

L'Echinoprocta rufescens (Hystricidaé), décrit par Gray en 1865, retrouvé en Colombie, pres de Bogotà. Bull. Mus. d'Hist nat., pp. 448-453, 3 figs. 1920. (Revised diagnoses of genus and species.)

Trodghton, Ellis Le G. Notes on Australian mammals. No. 1. Rec. Australian Mus., vol. 13, no. 3, pp. 118-122, figs. 1-6. December 4, 1920. (Chalinolobus morio, Eptesicus pumilus, Epimys assimilis.)

Willey, A. A question of bibliography. Science, n. s., vol. 52, pp. 608-609. December 24, 1920. (Asks for information as to what "Mr. Lockhart" is quoted in Coues' Fur-bearing Animals as authority for observation on habits of the wolverine.)

\title{
THE NORTHERN CALIFORNIA SECTION OF THE AMERICAN SOCIETY OF MAMMALOGISTS
}

The Northern California Section of the American Society of Mammalogists was started on January 8, 1920, when, at the suggestion of Dr. Joseph Grinnell, a meeting of persons interested in the study of mammals was held at the California Museum of Vertebrate Zoology in Berkeley. Organization was effected at that meeting and affiliation with the main Society was accomplished the following month. During the year 1920 nine meetings were held, there being a recess over the summer months when a number of the members were absent on field trips. The attendance has varied from five to fifteen but the degree of interest shown is far above that indicated by the attendance. Meetings of other scientific organizations in the San Francisco Bay region have made it impossible for all the local members to be present at each meeting of the section and absence on field trips has further interfered with attendance.

The field of interest has been quite wide although greater emphasis has been laid upon the life histories of mammals than upon any other one subject. The programs of the several meetings were as follows:

January 8, J. Grinnell, On kangaroo rats; J. Dixon, Trapping and trappers in central and southern California.

February 5, A. B. Howell, The California mastiff bat; Some Californian experiences with bat roosts (see this Journal, 1920, pp. 111-117; pp. 169-177).

March 4, Dane Coolidge, Collecting mammals in Italy and France in 1900.

April 1, J. Dixon, The golden beaver at Snelling, California.

May 6, Prof. C. A. Kofoid, Experiences with the wild mammals of southwestern British India.

August 26, Prof. J. S. Kingsley, Some reminiscences of vertebrate zoologists.

September 16, Symposium on the status of deer in the central coast counties of California.

October 28, "Book evening" at the University of California Library.

December 9 , Dr. T. T. Waterman, Indian legends relating to western mammals. 
One meeting during the year, that on September 16, was held in San Francisco, and one at the University Library, while the remainder were held at the Museum of Vertebrate Zoology. The greater part of the local membership resides in Berkeley and so most of the meetings are held there, but in fairness to those living in.San Francisco one or more meetings each year will be held in that city. The first Thursday of each month has been chosen as the regular meeting night and this plan will not be changed except in special circumstances. The organization has been maintained in as simple a manner as possible, the conduct of the meetings is quite informal, and the only levy during the past year was for the printing of meeting notices.

Those in attendance during the past year feel that much good has resulted from the Section and we would strongly urge that members of the Society in other localities combine in like manner and establish their own Sections.

It is the desire of the Section that members of the Society at large from other parts of the country, when in the Bay region, will get in touch with the Section and attend its meetings.-Tracy I. Storer, Secretary, Museum of Vertebrate Zoology, Berkeley, California. 


\section{$2 \mathrm{BHL}$ Biodiversity Heritage Library}

Storer, Tracy I. 1921. "The Northern California Section of the American Society of Mammalogists." Journal of mammalogy 2, 123-124.

View This Item Online: https://www.biodiversitylibrary.org/item/220033

Permalink: https://www.biodiversitylibrary.org/partpdf/90591

\section{Holding Institution}

Smithsonian Libraries

\section{Sponsored by}

Biodiversity Heritage Library

\section{Copyright \& Reuse}

Copyright Status: Not in copyright. The BHL knows of no copyright restrictions on this item.

This document was created from content at the Biodiversity Heritage Library, the world's largest open access digital library for biodiversity literature and archives. Visit BHL at https://www.biodiversitylibrary.org. 